\title{
Application of Ecological Indices using Macroinvertebrate Assemblages in Relation to Aquaculture Activities in Rawang Sub-basin, Selangor River, Malaysia
}

\author{
Nadeesha Dilani Hettige ${ }^{1,3}$, Rohasliney Binti Hashim ${ }^{1 *}$, Ahmad Bin Abas Kutty ${ }^{2}$, \\ Nor Rohaizah Binti Jamil ${ }^{1}$ and Zulfa Hanan Binti Ash'aari ${ }^{1}$
}

${ }^{1}$ Faculty of Forestry and Environment, Universiti Putra Malaysia, 43400 UPM, Serdang, Selangor, Malaysia ${ }^{2}$ School of Environmental \& Natural Resource Sciences, Universiti Kebangsaan Malaysia, 43600 UKM, Bangi Selangor, Malaysia

${ }^{3}$ Environmental Studies Division, National Aquatic Resource Research and Development Agency (NARA), Crow Island, Colombo 15, Sri Lanka

\begin{abstract}
This study aimed to evaluate benthic macroinvertebrates assemblages using the application of ecological indices in the Rawang sub-basin of the Selangor River with reference to determining the impacts of aquaculture practices on benthic macroinvertebrates. In total, seven sampling sites were selected, namely Guntong (SR1), Guntong's tributaries (SR2, control site), Kuang (SR3 and SR7), Gong (SR4), Buaya (SR5) and Serendah (SR6) Rivers. Sites were selected using a random sampling technique and the accessibility and proximity to aquaculture farms. Macroinvertebrates were sampled from April 2019 to March 2020 using an aquatic kick net, a hand spade, and a D-frame dip net. Water samples were also taken. Twenty-seven families belonging to the Annelida, Mollusca

ARTICLE INFO

Article history:

Received: 10 February 2020

Accepted: 13 November 2020

Published: 31 December 2020

DOI: https://doi.org/10.47836/pjst.28.S2.03

E-mail addresses:

nadeeshahettige7@gmail.com (Nadeesha Dilani Hettige) rohasliney@upm.edu.my (Rohasliney Binti Hashim) abas@ukm.edu.my (Ahmad Bin Abas Kutty) norrohaizah@upm.edu.my (Nor Rohaizah Binti Jamil) zulfa@upm.edu.my (Zulfa Hanan Binti Ash'aari)

*Corresponding author

and Athropoda phyla were identified using taxonomic keys. Tubificidae was found to be the most dominant family $(36.79 \%)$ followed by Chironomidae (28.84\%). The highest number of individuals from family Tubificidae was recorded in Gong River, where effluent was discharged from an aquaculture farm. The total abundance of benthic macroinvertebrates increased with increased proximity to the aquaculture farm. Based on Biological Monitoring Working
\end{abstract}


Party score value, the water quality of sampling sites in close proximity to the aquaculture farm was polluted as compared to the control location. Family Biotic Index score showed that all sites were substantially polluted with organic pollution, with the control site being much less polluted. In conclusion, benthic macroinvertebrates assemblage was affected by effluent originating from aquaculture farm outlets. It is therefore necessary to conduct aquaculture farming using methods that are deemed to be environmentally friendly.

Keywords: Benthic macroinvertebrates, biological monitoring working party, and family biotic index, diversity

\section{INTRODUCTION}

In recent years, the aquaculture industry has significantly expanded and become more efficient worldwide. This has been primarily to address increasing demands in food supply due to production limitations in capture fisheries (Saremi et al., 2013). Freshwater aquaculture, as one of the aquaculture industry activities, presents significant environmental problems for aquatic ecosystems worldwide (Krrkag et al., 2009). For instance, aquaculture activities nearby rivers generally discharge untreated wastewater into main water bodies. Over time, this leads to adverse changes in the water quality of aquatic environments including aquatic biota and their functional feeding traits (Minoo, 2015). The present situation has become a major concern in Malaysia (Hanafi et al., 1995; Kawasaki et al., 2016a; Yusoff, 2015). Previous reports had recorded the deleterious changes in water quality from aquaculture activities, among others, reduced diversity, replaced sensitive species, impacted native species and changed tropical structures of organisms (Diana, 2009). Karimi et al. (2016) in their studies in Dohezar Stream, Iran reported that populations of sensitive organisms had been reduced, and more tolerant species had survived and had become more dominant at fish farming sites. The effect diminished with increasing distance from discharge points of farm effluent.

Numerical values of several indices incorporating ecological responses of aquatic communities have been typically forming the basis of biological monitoring (Zhu \& Chang, 2008). Among the most commonly used indices include diversity indices (species richness, Shannon index), abundance (coverage, density and biomass) and pollution tolerance (Biological Monitoring Working Party (BMWP) and Biological Monitoring Water Quality score systems). The preceding research summarised that biological monitoring of pollution originating from fish farms in aquatic ecosystems is possibly more appropriate for use in indices based on benthic macroinvertebrates (Camargo et al., 2011; Karimi et al., 2016). Studies on the effects of aquaculture effluent on benthic macroinvertebrates have previously been reported using BMWP index (Hatami et al., 2011). Benthic macroinvertebrates have been documented to respond to a wide range of environmental changes caused by various anthropogenic impacts (Kim et al., 2016), including those arising from aquaculture activities 
(Hatami et al., 2011; Karimi et al., 2016; Minoo et al., 2016). Benthic macroinvertebrates have been considered as a good bioindicator in assessing river water quality (Oliveira \& Callisto, 2010; Young et al., 2014).

Among the major rivers in the State of Selangor, Selangor River is renowned for its freshwater aquaculture production area which increases of nearly 20,000 tonnes per year from 2008 to 2013 (Lembaga Urus Air Selangor [LUAS], 2015). The Rawang sub-basin is an important sub-basin of the Selangor River in which freshwater aquaculture has been more prevalent (LUAS, 2014). In previous initiatives, environmental monitoring of Selangor River focused only on physiochemical parameters of water. Some researches had highlighted the impact of pollution in the area by using physiochemical water quality assessments (Chowdhury et al., 2018; Daniel \& Kawasaki, 2016; Fulazzaky et al., 2010; Kawasaki et al., 2016a). According to Kawasaki et al. (2016a), it is cited that aquaculture ponds have been the major source of nutrients to the Selangor River. However, specific effects on aquatic organisms were not comprehensively discussed.

The influence of anthropogenic activities on benthic macroinvertebrates in streams and rivers in Malaysia have also been studied (Azrina et al., 2006; Hasmi et al., 2017; Ling, 2010; Rak et al., 2014, 2011). However, there has been no study focusing on the influence of aquaculture practices on benthic macroinvertebrates in streams using ecological indices. There has also been a lack of records on the diversity of benthic macroinvertebrates. It was against these backgrounds that the present multi-objective study was conducted. The first objective was to identify benthic macroinvertebrate assemblages in the Rawang sub-basin of the Selangor River using taxonomy keys. The second objective was to apply ecological indices to evaluate water quality status. The final study objective was to determine the impacts of aquaculture practices on benthic macroinvertebrates in selected rivers within the study area.

\section{MATERIALS AND METHODS}

\section{Site Description}

The Selangor River, one of the major rivers in the State of Selangor, flows from the Titiwangsa Range of Banjaran Titiwangsa (The Main Range in Peninsular Malaysia) beginning at the foothills of Fraser's Hill. Ultimately, the Selangor River makes its way west to the Straits of Malacca at Kuala Selangor town (Seyam \& Othman, 2015). The catchment area of the river is nearly $2200 \mathrm{~km}^{2}$ with a length of almost $110 \mathrm{~km}$. The river flows through the districts of Hulu Selangor, Kuala Selangor and Gombak. It has seven main tributaries (Othman et al., 2014) and is divided into ten sub-basins based on hydrological boundaries (Chowdhury et al., 2018). Approximately 50\% of the river basin is still covered by natural forests and $22 \%$ has agricultural activities (Othman et al., 2014). The upper part of the catchment consists mainly of granite and sedimentary bedrocks. Parts of the basin's 
mid-section comprise granite rocks with meta-sedimentary face carboniferous rocks. The mid-section of the catchment is also underlined with limestone and interbedded schist (Hamzah et al., 2007). There is a rich aquatic and terrestrial life in the basin such as a firefly reserve, mangroves, migratory birds and peat swamp forests (LUAS, 2015). There exist approximately 300 freshwater and 50 brackish water aquaculture ponds along the Selangor River basin (Kawasaki et al., 2016b), including extensive aquaculture farming areas in the Rawang sub-basin.

\section{Research Design}

In the present study, site selection was done using a random sampling technique while taking into account a site's accessibility as well as its proximity to aquaculture farms. Accordingly, seven sampling sites (Figure 1) were selected along the following rivers: Guntong (SR1), Guntong's tributaries (SR2), Kuang (SR3 and SR7), Gong (SR4), Buaya (SR5) and Serendah (SR 6). SR2 served as the control site due to its minimal disturbance in its surrounding area and the absence of upstream aquaculture farms. The following are approximate downstream distances (in metres, $\mathrm{m}$ ) from the sampling site to the nearest freshwater aquaculture farms: SR1 and SR3 (200 m), SR4 and SR5 (20 m), SR6 (400 m) and SR7 $(400 \mathrm{~m})$. There was no point source of pollution that discharged directly into the river between the aquaculture farm outlets and the sampling points. Sampling sites were located near to the riverbanks.

A sampling of benthic macroinvertebrates was carried out from April 2019 until February 2020. However, additional sampling visits were conducted until a proper rarefaction curve was attained in March 2020. Samples were collected using three types of sampling gears, namely a D-frame dip net, an aquatic kick net and a hand spade $(\mathrm{N}=$ 7 sampling $\times 1$ river basin $\times 7$ stations $\times 3$ gear types $\times 5$ replicates $=735$ samples per river basin). To obtain samples from the $\mathrm{D}$-frame net and aquatic kick net, the nets were placed against the flow of current and approximately one square meter of the substrate in front of the nets was disturbed for nearly two minutes using the kick sampling method (Merritt \& Cummins, 1996). The hand-scooping method was used with a hand spade to collect sediment samples below (nearly $5 \mathrm{~cm}$ depth) the edge of the river's water level. Collected samples were then poured into polythene bags and transported directly to the Aquatic Laboratory, Faculty of Forestry and Environment, Universiti Putra Malaysia (UPM) for further analysis. In the laboratory, samples were wet-sieved using a $0.5 \mathrm{~mm}$ of fine mesh size sieve and separated according to particle size. After separation, benthic macroinvertebrates were sorted and preserved in $70 \%$ ethanol for storage prior to further analysis. Macroinvertebrates were identified to the nearest taxonomic unit using a dissecting microscope, a compound microscope and by using standard identification keys (Burnhill, 
2006; Brinkhurst \& Jamieson, 1971; Brinkhurst, 1971; Merritt \& Cummins, 1996; Thorp \& Lovell, 2014; Yong \& Yule, 2004).

In addition to the benthic macroinvertebrates, water samples were taken from each sampling site at two-monthly intervals from April 2019 to February 2020. During the sampling work, three replicate samples were collected at each site for the purpose of physiochemical water quality analysis $(\mathrm{N}=1$ river basin $\times 7$ sampling sites $\times 6$ sampling trips $\times 3$ replicates $=126$ samples per river basin). Water temperature, dissolved oxygen (DO), electrical conductivity (EC), turbidity and $\mathrm{pH}$ were measured in-situ by using the following equipment: dissolved oxygen meter (YSI 52, USA), conductivity meter (Thermo Scientific Orion 3-Star, USA), turbidity meter (HACH 2100 P, USA) and pH meter (Thermo Scientific Orion 3-Star, Indonesia) respectively. All portable meters were duly calibrated before use.

Collected water samples were transported to the laboratory at $4{ }^{\circ} \mathrm{C}$ for subsequent laboratory analysis. Chemical Oxygen Demand (COD) and ammoniacal nitrogen testing were performed using a DR 2800 spectrophotometer (HACH, 2007), while Biochemical Oxygen Demand 5 (BOD5) was measured using a BOD probe (Verma \& Singh, 2013). Total suspended solids (TSS) were quantified using a standard method (American Public Health Association, 2012).

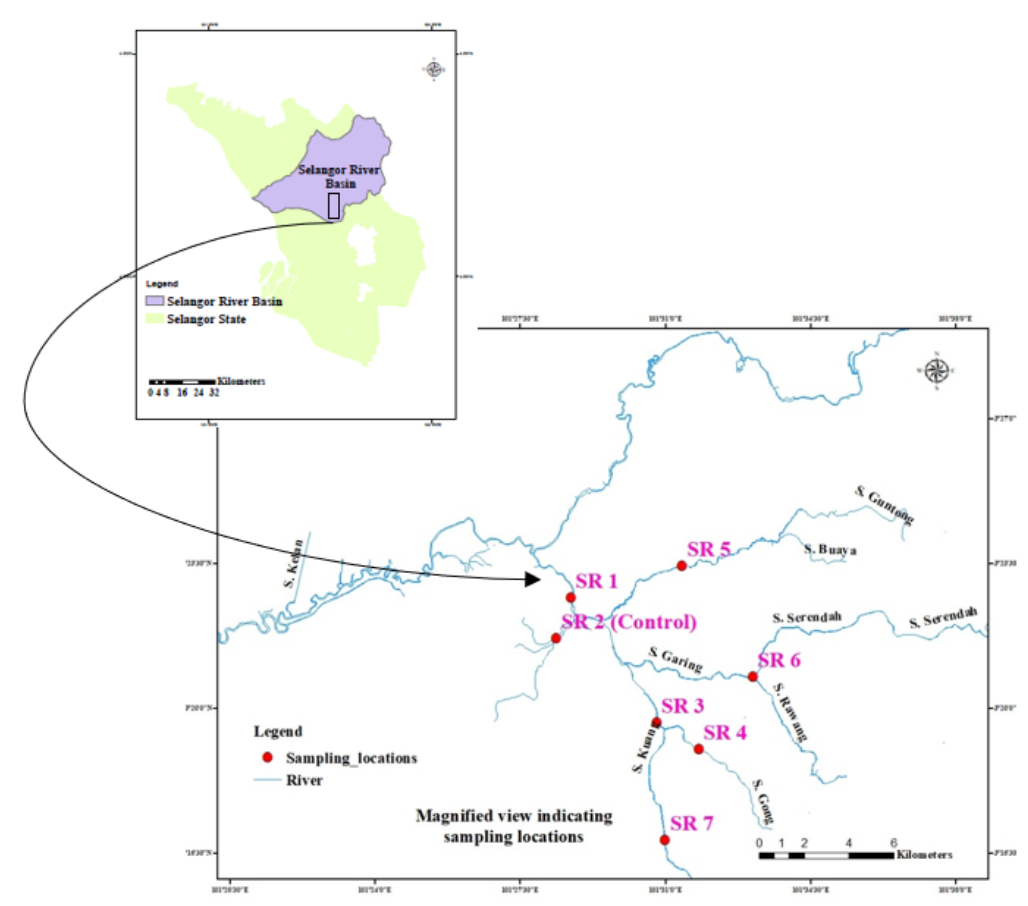

Figure 1. Map of the Selangor River in the State of Selangor and the chosen study area showing selected sampling locations 


\section{Data Analysis}

The effects of land use and macroinvertebrate biotic indices on rivers have been studied by several researchers (Fierro et al., 2017; Hatami et al., 2011; Karimi et al., 2016; Kim et al., 2016; Kroll et al., 2009; Lalonde et al., 2016; Virbickas et al., 2011). In the present study, several ecological indices were used to express the diversity of benthic macroinvertebrates and water's pollution status, namely by Shannon's Diversity Index (H'), Simpson's Diversity Index (D), Biological Monitoring Working Party-Thailand (BMWP ${ }^{\text {Thai }}$ ) and the Family Biotic Index (FBI). These indices were calculated based on the family level of benthic macroinvertebrates. The calculation methods for these indices are presented in Table 1.

The tolerance value of taxa was used to calculate the FBI following Mandaville (2002) and Hilsenhoff (1988) and the FBI table is presented in Table 2. Tolerance values ranged from 0 (very intolerant of organic wastes) to 10 (very tolerant of organic wastes). Table 3 presents the BMWP ${ }^{\text {Thai }}$ score ranges and their corresponding water quality status. The tolerance value of each family was used to calculate the BMWP Thai (Mustow, 2002). It assigns scores to each family according to its sensitivity to organic pollution. The highest value was given to the most sensitive family.

Table 1

Ecological Indices used to determine benthic macroinvertebrates diversity and pollution status

\begin{tabular}{lll}
\hline Index Name & Formula used/Method & References \\
\hline Shannon's index (H') & $-\sum_{i=1}^{S}$ pilnln $(p i)$ & Shannon (1948) \\
Simpson's Diversity Index (D) & $1-\left(\frac{\sum n(n-1)}{N(N-1)}\right)$ & Simpson (1949) \\
Biological Monitoring Working & $\begin{array}{l}\text { Sum of the tolerance scores } \\
\text { of macroinvertebrates } \\
\text { farty - Thailand (BMWP Thai })\end{array}$ & Mustow (2002) \\
Family Biotic Index (FBI) & $\frac{\text { Total (n×a) }}{\text { Total (n) }}$ & Hilsenhoff (1988) \\
\hline
\end{tabular}

Where,

pi : Proportion of species (i) relative to the total number of species

$\mathrm{S}:$ Number of taxa

$\mathrm{n}:$ Total number of organisms of a particular species

$\mathrm{N}$ : Total number of organisms of a particular species

a : Tolerance value 
Table 2

Family Biotic Index (FBI) Informative table used to evaluate river water quality

\begin{tabular}{lll}
\hline FBI & Water Quality & Degree of pollution \\
\hline $0.00-3.75$ & Excellent & Organic pollution unlikely \\
$3.76-4.25$ & Very Good & Possible slight organic pollution \\
$4.26-5.00$ & Good & Some organic pollution probable \\
$5.01-5.75$ & Fair & Fairly substantial pollution likely \\
$5.76-6.50$ & Fairly poor & substantial pollution likely \\
$6.51-7.25$ & Poor & Very substantial pollution likely \\
$7.26-10.00$ & Very poor & Sever organic pollution likely \\
\hline
\end{tabular}

Source: Hilsenhoff (1988)

Table 3

$B M W P^{\text {Thai }}$ score values and corresponding water quality status

\begin{tabular}{ll}
\hline BMWP $^{\text {Thai }}$ Score & Category \\
\hline$>151$ & Excellent \\
$101-150$ & Good \\
$51-100$ & Moderate \\
$17-50$ & Moderate Poor \\
$0-16$ & Very Poor \\
\hline
\end{tabular}

Source: Mustow (2002)

Statistical analysis was performed using Statistical Package for Social Sciences (SPSS) 25.0. The Kolmogorov-Smirnov test (Mishra et al., 2019) was used to determine whether the ecological index data and water quality were normally distributed. As the data were subsequently determined to be normally distributed, Pearson correlation analysis was carried out to determine the relationship between water quality and ecological indices. Subsequently, Canonical Correspondence Analysis (CCA) was used to identify the relationships composition between macroinvertebrates and relevant environmental variables using Paleontological Statistics (PAST), a statistical software. Three taxa, namely Cladoceran, Dytiscidae and Ephydridae, recorded only one individual being sampled within the sub-basin during the study period. Therefore, they were excluded from the proceeding data analyses, except for percentage calculation. 


\section{RESULTS AND DISCUSSION}

In the present study, a total of 7677 discrete individuals belonging to 27 families were identified. The families encompassed three phyla and five classes as shown in Table 4. Among the collected samples, Tubificidae was the most dominant family (36.79\%) with Chironomidae as the second-most dominant (28.84\%). Additionally, individuals from the Naididae family comprised $15.93 \%$ of the total abundance (Figure 2).

According to the results obtained, Tubificidae was found to be the dominant family within the sub-basin. It has been reported that Tubificidae is an effective biological indicator of water quality in streams (Martins et al., 2008). Tubificidae is also widely used as an indicator of organic pollution in rivers. Muddy sediments that are highly contaminated with organic matter facilitate the growth of the individual from the Tubificidae family. Therefore, an abundance of Tubificidae is an indicator of poor river water quality (Burnhill, 2006). In addition, based on a study conducted by Namin et al. (2013) on the impact of fish farm effluents on benthic macroinvertebrates of the Tajan River, Iran, members of the Tubificidae family were found in all of the selected locations including the control sites.

In the present study, the family Chironomidae was recorded to be the second most dominant family in the study area. The family had also been recorded at most other polluted areas (Al-Shami et al., 2010; Azrina et al., 2006) and recreational areas surrounding Malaysian streams and rivers (Ahmad et al., 2008; Muhazar et al., 2013; Rak et al., 2014). Chironomus larvae were the most dominant species found in the Tajan River in northern Iran, a river significantly impacted by aquaculture activities (Namin et al., 2013). Chironomidae has also been found in sampling stations downstream of a trout farm in Dohezar, Iran (Karimi et al., 2016). There has been no existing record of benthic macroinvertebrates in the Selangor River to compare with the results obtained from the present study.

The distribution and the total number of benthic macroinvertebrates at the family level from each sampling site are shown in Table 5. The highest total number of individuals from the dominant family (Tubificidae) was recorded from the Gong River (SR4), where aquaculture effluent was previously discharged. The lowest number of individuals from the family Tubificidae was recorded at the control site, that is, the Guntong River tributary sampling station (SR 2). Benthic macroinvertebrates from the Palaemonidae, Thiaridae and Caenidae families were most abundant.

Soonthornvipat et al. (2012) reported that oligochaetes constituted an ideal food source for various types of aquaculture fish including ornamental ones. They can survive in highly contaminated sites such as those with high turbidity, in the presence of toxic materials and high levels of organic matter content (Kang et al., 2017). Coldebella et al. (2018) recorded that COD, suspended and total solids in addition to the concentrations of some nutrients significantly increased during the time of harvest at aquaculture farms, which released 
Table 4

Taxonomic list of benthic macroinvertebrates recorded at selected study sites

\begin{tabular}{|c|c|c|c|}
\hline Phylum & Class & Order & Family \\
\hline Annelida & Clitellata & - & Aeolosomatidae \\
\hline Annelida & Clitellata & Haplotaxida & Naididae \\
\hline Annelida & Clitellata & Haplotaxida & Haplotaxidae \\
\hline Annelida & Clitellata & Haplotaxida & Tubificidae \\
\hline Annelida & Clitellata & Lumbriculida & Lumbriculidae \\
\hline Annelida & & - & $\begin{array}{l}\text { Unidentified } \\
\text { Oligochaeta }\end{array}$ \\
\hline \multirow[t]{2}{*}{ Annelida } & Clitellata & Rhynchobdellida & Glossiphoniidae \\
\hline & & Arhynchobdellida & Erpobdellidae \\
\hline \multirow[t]{2}{*}{ Arthropoda } & Insecta & Diptera & Chironomidae \\
\hline & & Diptera & Ephydridae \\
\hline Arthropoda & Malacostraca & Decopoda & Palaemonidae \\
\hline \multirow[t]{5}{*}{ Arthropoda } & Insecta & Odonata & Gomphidae \\
\hline & & & Libellulidae \\
\hline & & & Corduliidae \\
\hline & & & Protoneuridae \\
\hline & & & Coenagrionidae \\
\hline \multirow[t]{3}{*}{ Arthropoda } & Insecta & Ephemeroptera & Caenidae \\
\hline & & & Baetidae \\
\hline & & & Leptophlebiidae \\
\hline \multirow[t]{3}{*}{ Arthropoda } & Insecta & Coleoptera & Dytiscidae \\
\hline & & Trichoptera & Hydropsychidae \\
\hline & Branchiopoda & Cladocera & - \\
\hline \multirow[t]{4}{*}{ Mollusca } & Gastropoda & Architaenioglossa & Viviparidae \\
\hline & & Hygrophila & Lymnaeidae \\
\hline & & Neotaenioglossa & Thiaridae \\
\hline & & Hygrophila & Planorbidae \\
\hline Mollusca & Bivalve & Cardiida & Corbiculidae \\
\hline
\end{tabular}




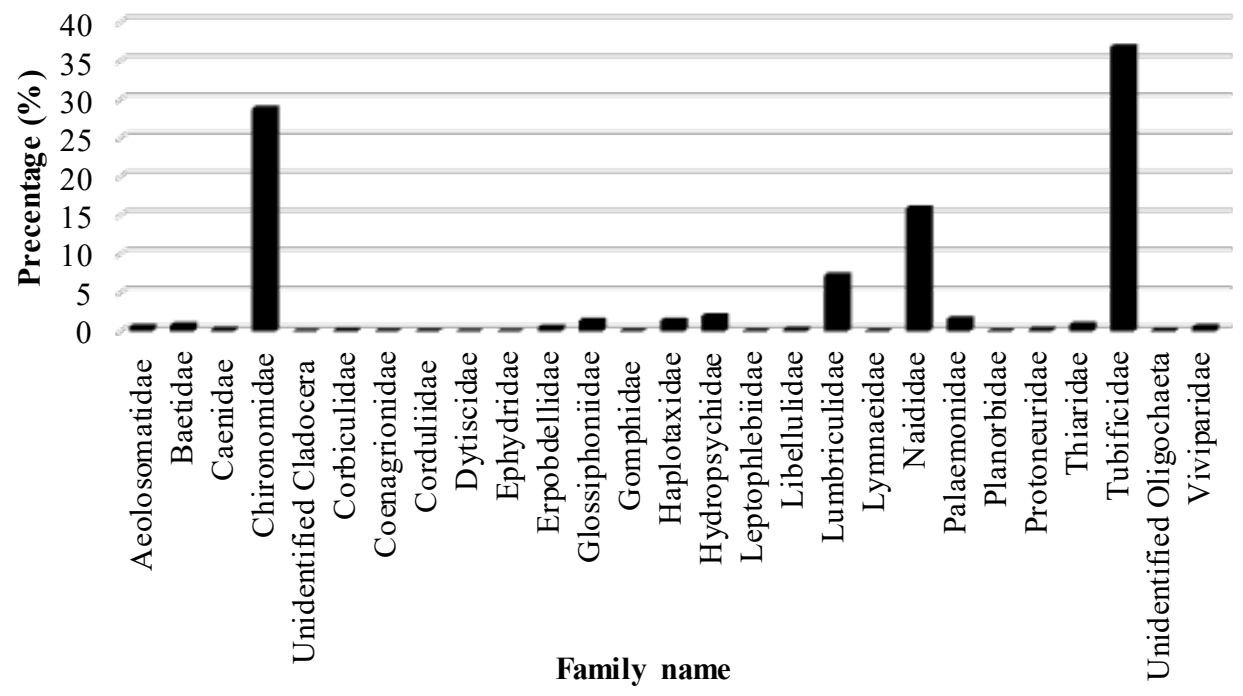

Figure 2. Percentage of individuals from families recorded at all sampling sites in the Rawang sub-basin

Table 5

Number of individuals at sampling sites distributed according to family

\begin{tabular}{llllllll}
\hline \multirow{2}{*}{ Family } & \multicolumn{7}{c}{ Number of Individuals } \\
\cline { 2 - 8 } & SR 1 & SR 2 & SR 3 & SR 4 & SR 5 & SR 6 & SR 7 \\
\hline Aeolosomatidae & 7 & - & 10 & 19 & 3 & 2 & 4 \\
Baetidae & - & 5 & - & - & - & 58 & - \\
Caenidae & - & 18 & - & - & - & 1 & 1 \\
Chironomidae & 180 & 8 & 202 & 287 & 810 & 414 & 313 \\
Unidentified & - & - & - & - & - & 1 & - \\
Cladocera & & & & & & & \\
Corbiculidae & - & - & - & - & - & 11 & - \\
Coenagrionidae & 1 & - & 2 & - & - & - & - \\
Corduliidae & 1 & 1 & 1 & - & 2 & - & - \\
Dytiscidae & - & - & - & - & 1 & - & - \\
Ephydridae & - & - & - & 1 & - & - & - \\
Erpobdellidae & 29 & 5 & - & 1 & 1 & - & 5 \\
Glossiphoniidae & 48 & 3 & 27 & 2 & 17 & 2 & 7 \\
Gomphidae & - & 3 & - & - & - & 2 & - \\
Haplotaxidae & 21 & 13 & 39 & 3 & 26 & 1 & 5 \\
\hline
\end{tabular}


Table 5 (Continued)

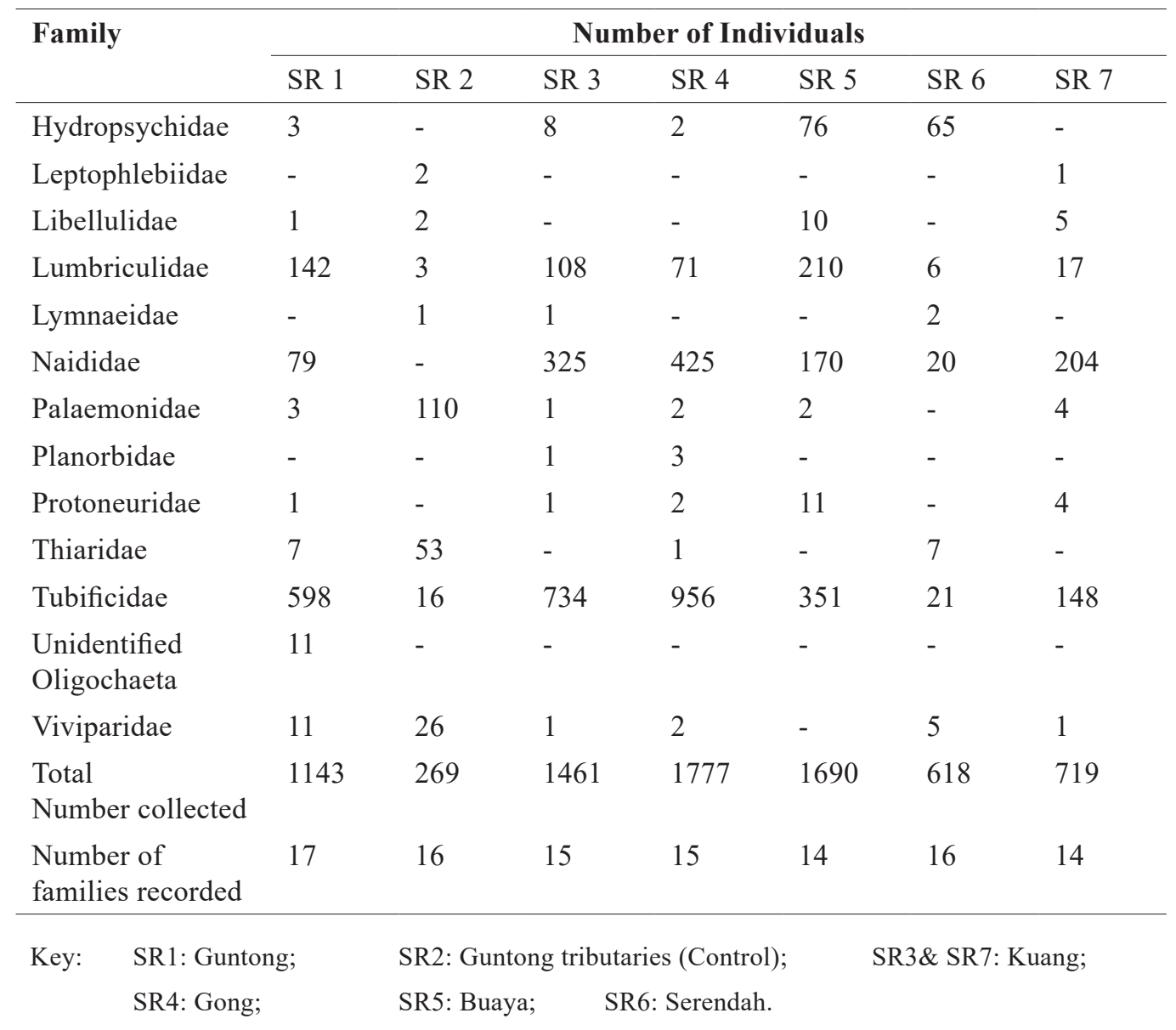

effluents into the environment. Effluents from aquaculture farms have been documented to facilitate the creation of suitable conditions for oligochaetes in receiving streams. In the present study, the sampling site at Gong River (SR 4) was in closest proximity to an aquaculture farm effluent outlet, which explained the high number of Tubificidae being recorded. Minoo et al. (2016) noted that the total abundance of benthic macroinvertebrates increased consistently near to and immediately downstream from effluent discharge points of aquaculture farms. The present study observed that the total number of individuals recorded at other sampling sites based on their proximity to other aquaculture farms was in the following descending order: Buaya River, Kuang River (SR3), Guntong River, Kuang River (SR7) and Serendah River. This observation suggests that water quality significantly improved at some distances away from the outfalls of aquaculture farms. Hatami et al. (2011) concurred with the present findings. Other studies reported that downstream inland 
fish farms recorded lower diversity and taxa loss of macroinvertebrates (Lalonde et al., 2016). The recovery of stream fauna could occur even at long distances from aquaculture effluent outlets. From a spatial aspect, previous studies reported that at distances of up to $1,000 \mathrm{~m}$ downstream from a fish farm discharge point, changes in abundance and diversity have been detected (Camargo, 1992).

Table 6 shows the values of ecological indices sorted according to sampling sites and their respective water quality status. Highest values in both family richness level and Shannon Diversity Index (H') were found at the control sites of Guntong River tributary (SR2). Lower levels of family richness were recorded at sites just below the aquaculture farms (SR4 and SR5). This suggests a reduction in water quality when compared with the control site. Comparable findings were recorded in a preceding study by Loch et al. (1996) for EPT taxa richness due to fish farm effluent. However, family richness was observed to be higher in Kuang River (SR7) and Serendah River (SR6) than Guntong River (SR1) and Kuang River (SR3). This was because the sampling points of Kuang River (SR7) and Serendah River (SR6) were located further downstream from the aquaculture farm effluent discharge point as compared to the sampling sites at Guntong River (SR1) and Kuang River (SR3). The observation suggests that water quality of Kuang River (SR7) and Serendah River (SR6) were improving. However, the highest Simpson's Diversity Index was recorded from the control site (SR2) while Serendah River (SR6) showed the lowest. The highest value of FBI was recorded from Guntong River (SR1) sampling stations while the lowest was reported from the control site (SR2).

According to the $\mathrm{H}^{\prime}$ index, all the sampling sites were classified as having moderately polluted water $\left(1<\mathrm{H}^{\prime}<2\right)$ (Li-na et al., 2017). Guntong River, Kuang River, Gong River and Buaya River had very poor water quality status while Serendah River and Guntong's tributary were poor and fairly poor, respectively (Hilsenhoff, 1988). Therefore, the control site (SR2), which was located at Guntong River's tributaries, was also classified as having low water quality (Table 6).

Water quality evaluation results could change when integrated health monitoring is conducted. The classification of water quality status at sampling sites based on their corresponding BMWP ${ }^{\text {Thai }}$ is also shown in Table 6.

The water quality of the Control river (SR2) was categorised as "Moderate" based on its BMWP ${ }^{\text {Thai }}$ value. Because the site was located in a place with minimal disturbances and organisms from pollution-sensitive families (Leptophlebiidae, Corduliidae and Caenidae) were found here, the family level pollution-sensitive score for BMWP index was correspondingly high. Since there were differences in water quality levels for the same sampling site from BMWP and FBI, it was difficult to evaluate water quality accurately because biological analysis based on the composition of benthic macroinvertebrates could 
Table 6

Species richness, diversity indices and biotic index at the study area's sampling sites

\begin{tabular}{|c|c|c|c|c|c|}
\hline $\begin{array}{l}\text { Sampling } \\
\text { site }\end{array}$ & $\begin{array}{l}\text { Family level } \\
\text { richness }\end{array}$ & $\begin{array}{l}\text { Shannon } \\
\text { Diversity Index }\end{array}$ & $\begin{array}{l}\text { Simpson's } \\
\text { Diversity } \\
\text { Index }\end{array}$ & $\begin{array}{l}\text { Biological } \\
\text { Monitoring } \\
\text { Working } \\
\text { Party Thai }\end{array}$ & $\begin{array}{l}\text { Family } \\
\text { Biotic } \\
\text { Index }\end{array}$ \\
\hline SR 1 & 0.50 & $\begin{array}{l}1.54 \\
\text { Moderately } \\
\text { polluted }\end{array}$ & 0.68 & $\begin{array}{l}57 \\
\text { Moderate }\end{array}$ & $\begin{array}{l}8.09 \\
\text { Very Poor }\end{array}$ \\
\hline SR 2 & 0.98 & $\begin{array}{l}1.92 \\
\text { Moderately } \\
\text { polluted }\end{array}$ & 0.78 & $\begin{array}{l}70 \\
\text { Moderate }\end{array}$ & $\begin{array}{l}6.38 \\
\text { Fairly Poor }\end{array}$ \\
\hline SR 3 & 0.39 & $\begin{array}{l}1.42 \\
\text { Moderately } \\
\text { polluted }\end{array}$ & 0.67 & $\begin{array}{l}50 \\
\text { Moderately } \\
\text { poor }\end{array}$ & $\begin{array}{l}8.01 \\
\text { Very Poor }\end{array}$ \\
\hline SR 4 & 0.33 & $\begin{array}{l}1.22 \\
\text { Moderately } \\
\text { polluted }\end{array}$ & 0.63 & $\begin{array}{l}41 \\
\text { Moderately } \\
\text { poor }\end{array}$ & $\begin{array}{l}7.99 \\
\text { Very Poor }\end{array}$ \\
\hline SR 5 & 0.32 & $\begin{array}{l}1.51 \\
\text { Moderately } \\
\text { polluted }\end{array}$ & 0.70 & $\begin{array}{l}41 \\
\text { Moderately } \\
\text { poor }\end{array}$ & $\begin{array}{l}7.84 \\
\text { Very Poor }\end{array}$ \\
\hline SR 6 & 0.60 & $\begin{array}{l}1.23 \\
\text { Moderately } \\
\text { polluted }\end{array}$ & 0.53 & $\begin{array}{l}47 \\
\text { Moderately } \\
\text { poor }\end{array}$ & $\begin{array}{l}7.10 \\
\text { Poor }\end{array}$ \\
\hline SR 7 & 0.52 & $\begin{array}{l}1.40 \\
\text { Moderately } \\
\text { polluted }\end{array}$ & 0.69 & $\begin{array}{l}53 \\
\text { Moderate }\end{array}$ & $\begin{array}{l}8.02 \\
\text { Very Poor }\end{array}$ \\
\hline Key: & $\begin{array}{l}\text { SR1: Guntong; } \\
\text { SR4: Gong; }\end{array}$ & \multicolumn{3}{|c|}{ SR2: Guntong tributaries (Control); } & SR7: Kuang; \\
\hline
\end{tabular}

not be considered as a single factor to determine water quality status since it also depended on environmental factors (Surtikanti, 2016).

Pearson correlational analysis revealed that BMWP ${ }^{\text {Thai }}$ was negatively correlated with TSS $(r=-0.768 ; \mathrm{P}<0.05)$. Similar outcomes with regards to the correlation between BMWP ${ }^{\text {Thai }}$ and suspended solids were reported by Kullasoot et al. (2017) based on studies conducted in Mae Klong River, Thailand. This further validated that macroinvertebrates could serve as an indicator for deteriorating water quality. A positive correlation was revealed between FBI and COD $(r=0.786 ; \mathrm{P}<0.05)$, TSS $(\mathrm{r}=0.866 ; \mathrm{P}<0.05), \mathrm{EC}(\mathrm{r}=$ $0.960 ; \mathrm{P}<0.01)$, BOD $(\mathrm{r}=0.877 ; \mathrm{P}<0.01)$. Similar correlations were reported by Etemi et al. (2020) between FBI and BMWP with the above mentioned water quality parameters of 
the Lepenci River basin in Kosovo. The family level richness was reported to be negatively correlated with EC $(r=-861: p<0.05)$, ammoniacal nitrogen $(r=-0.791: p<0.05)$, BOD $(\mathrm{r}=-0.857: \mathrm{p}<0.05), \operatorname{COD}(\mathrm{r}=-0.826: \mathrm{p}<0.05)$ and TSS $(\mathrm{r}=-0.912: \mathrm{p}<0.01)$. Based on a study conducted in the Tajan River in Iran by Namin et al. (2013), it was indicated that none of the correlational coefficients between water's physicochemical parameters and macroinvertebrates metrics and indices were insignificant. However, the correlational analysis conducted in the present study had allowed environmental variables to explain the variations of the indices due to aquaculture farming activities.

The CCA consisted of seven parameters, including $\mathrm{pH}$, DO, water temperature, ammoniacal nitrogen, TSS, turbidity, EC. BOD, DO and COD, were significant in the composition of the benthic macroinvertebrate communities (Figure 3). The first and second CCA axes together accounted for approximately $89.17 \%$ of the relation between benthic macroinvertebrate communities and environmental variables. The length of the arrows in the CCA revealed that DO, TSS, turbidity, COD, ammoniacal nitrogen and BOD values were the main environmental factors affecting the distribution of benthic macroinvertebrates in the Rawang sub-basin of the Selangor River. Additionally, the arrow length for $\mathrm{pH}$ was the shortest in length which denoted a scant relationship between family and $\mathrm{pH}$. However, $\mathrm{pH}$ was an important parameter for all organisms in any given aquatic ecosystem. As cited by the United States Environmental Protection Agency (USEPA), a pH range of 6.5 to 9.0 was suitable for bottom-dwelling macroinvertebrates (Prommi \& Payakka, 2015). The number of individuals and taxa are very sensitive to the low $\mathrm{pH}$ of the aquatic ecosystem (Petrin et al., 2007). Both EC and water temperature also assert influence to some extent on variations in benthic macroinvertebrates communities.

The first quadrant of the CCA contained the families Baetidae, Corbiculidae, Corduliidae, Erpobdelliae, Gomphidae, Hydropsychidae, Libellulidae and Lymnaeidae. These families were influenced by high DO. DO concentration is an essential limnological factor for the characterisation of aquatic ecosystems and the survival of aquatic life (Moura et al., 2011). Preceding research conducted at the Teroi and Batu Hampar rivers of Gunung Jerai forest reserve, Kedah by Hamid et al. (2011) reported that genus Baetis (family Baetidae) had a positive correlation with DO. Nevertheless, based on a study conducted in the lower catchment of the Kinabatangan River, Sabah, Harun et al. (2015) reported that Coenagrionidae and Libellulidae were declined in the high concentrations of DO. The families in the second quadrant, especially Glossiphoniidae, Lumbriculidae, Protoneuridae, Chironomidae and unidentified Oligochaeta, were highly influenced by TSS, turbidity and COD. The said families had moderate relationship with water temperature. Sharma and Chowdhary (2011) reported that the presence of Lumbriculidae contributed to increase in TSS. Glossiphoniidae (some Helobdella sp.) can be considered as tolerant of physical water quality factors such as turbidity and TSS (Miserendino \& Gullo, 2014). 
Families located in the third quadrant were Aelosomadidae, Naididae, Coenagrionidae, Planorbidae and Tubificidae. All of these families had similar environmental selections and easily coexisted with high BOD, ammoniacal - nitrogen and EC. The said families had little relationship with $\mathrm{pH}$. As $\mathrm{pH}$ increased, the recolonization of benthos occurred and $\mathrm{pH}$ positively affected benthic production in tropical waters (Vizakat et al., 1991). Based on a study conducted in Pauh River located at Cameron Highlands, Tan and Beh (2016) observed that Planorbidae and Tubificidae were positively correlated with EC, BOD and ammoniacal nitrogen. The fourth quadrant comprised families Caenidae, Haplotaxidae, Leptophlebiidae, Palaemonidae, Thiaridae and Viviparidae. No measured water quality parameters influenced the families.

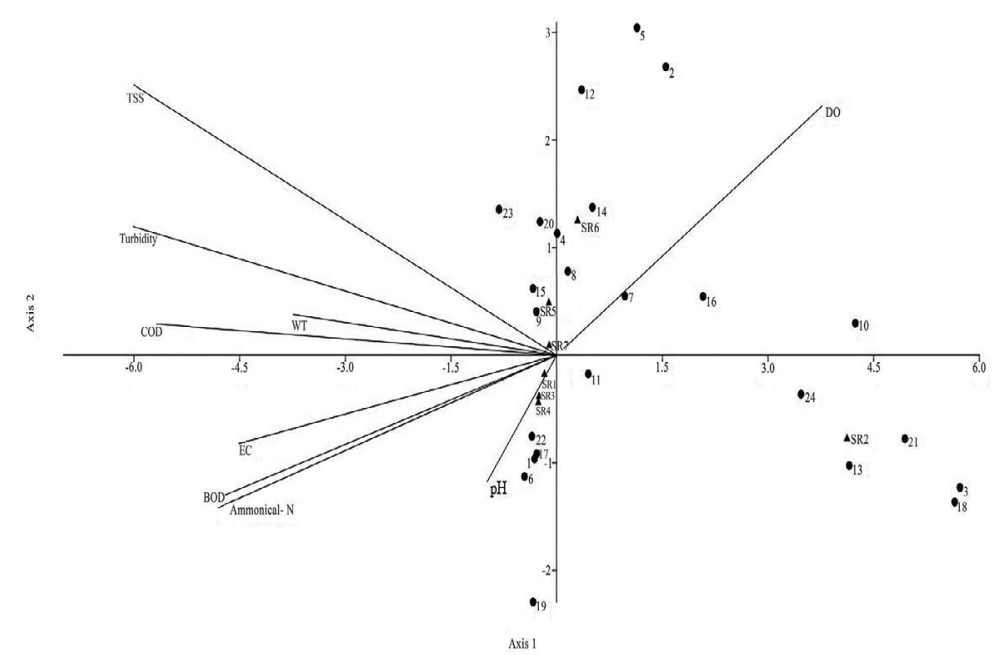

\begin{tabular}{|c|c|c|c|c|c|c|c|}
\hline 1. & Aeolosomatidae & 7. & Corduliidae & 13. & Leptophlebiidae & 19. & Planorbidae \\
\hline 2. & Baetidae & 8. & Erpobdellidae & 14. & Libellulidae & 20. & Protoneuridae \\
\hline 3. & Caenidae & 9. & Glossiphoniidae & 15. & Lumbriculidae & 21. & Thiaridae \\
\hline 4. & Chironomidae & 10. & Gomphidae & 16. & Lymnaeidae & 22. & Tubificidae \\
\hline 5. & Corbiculidae & 11. & Haplotaxidae & 17 & Naididae & 23. & $\begin{array}{l}\text { Unidentified } \\
\text { Oligochaeta }\end{array}$ \\
\hline 6. & Coenagrionidae & 12. & Hydropsychidae & 18. & Palaemonidae & 24. & Viviparidae \\
\hline
\end{tabular}

Figure 3. Canonical Correspondence Analysis (CCA) diagram indicating the relationship between benthic macroinvertebrates families and correlations with environmental parameters 


\section{CONCLUSION}

The present study revealed the occurrence of 27 families of benthic macroinvertebrates in the selected rivers of the Rawang sub-basin using taxonomic keys. Based on the values of ecological indices, the clear differences based on proximity to the aquaculture farming discharge point were not discernible because some organisms were able to tolerate environmental stresses fairly well. Consequently, based on BMWP, the findings of the present study indicated that the water quality from sampling sites near the aquaculture farm was polluted as compared to the control station. With respect to environmental quality, the FBI values indicated that all sites were substantially polluted with organic pollution. The control sites possessed the highest water quality, while the Buaya and Gong rivers which were near to aquaculture farm effluent discharge points exhibited the lowest quality of water in the Rawang sub-basin. Nevertheless, further studies are needed to better interpret the impacts of aquaculture farms on pollution levels through the development of the modelling approach.

\section{ACKNOWLEDGEMENTS}

The authors gratefully thank and acknowledge the research grant provided by the Ministry of Higher Education (MOHE), Malaysia for funding this work under Trans-Disciplinary Research Grant Scheme (TRGS/2016/5535713). The authors also express their gratitude to Miss Xeai Li Chai, a postgraduate student from the Faculty of Forestry and Environment, UPM and Miss Hanisah Binti Ibrahim, a PhD student from the School of Environmental \& Natural Resource Sciences, UKM, for their assistance in fieldwork and laboratory work, respectively. Special thanks are also due to the technical staff, Faculty of Forestry and Environment, UPM, for their invaluable help in field sampling arrangements.

\section{REFERENCES}

Ahmad, A. K., Idris, A. B., Othman, M. S., Salwana, H., \& Hamisah, H. (2008). A preliminary survey of chironomids diversity at headwater of Langat River, Selangor. Serangga, 13(1-2), 1-18.

Al-Shami, S. A., Md Rawi, C. S., Ahmad, A. H., \& Nor, S. A. M. (2010). Distribution of Chironomidae (Insecta: Diptera) in polluted rivers of the Juru River Basin, Penang, Malaysia. Journal of Environmental Sciences, 22(11), 1718-1727. doi:10.1016/S1001-0742(09)60311-9

American Public Health Association. (2012). Standard methods for the examination of water and waste water (22nd Ed.). Washington, USA: American Public Health Association (APHA), American Water Works Association (AWWA) and Water Environment Federation (WEF).

Azrina, M. Z., Yap, C. K., Rahim Ismail, A., Ismail, A., \& Tan, S. G. (2006). Anthropogenic impacts on the distribution and biodiversity of benthic macroinvertebrates and water quality of the Langat River, Peninsular Malaysia. Ecotoxicology and Environmental Safety, 64(3), 337-347. doi:10.1016/j. ecoenv.2005.04.003 
Brinkhurst, R. O. (1971). A guide for the identification of British Aquatic Oligochaeta (2nd Ed.). Toronto, Canada: Titus Wilson \& Sons LTD.

Brinkhurst, R. O., \& Jamieson, B. M. G. (1971). Aquatic oligochaeta of the world. Edinburgh, Scotland: Oliver \& Boyd.

Burnhill, T. (2006). Identification of freshwater invertebrates of the Mekong River and its tributaries. Vientiane, Laos: Mekong River Commission.

Camargo, J. A. (1992). Temporal and spatial variations in dominance, diversity and biotic indices along a limestone stream receiving a trout farm effluent. Water, Air, and Soil Pollution, 63(3-4), 343-359.

Camargo, J. A., Gonzalo, C., \& Alonso, Á. (2011). Assessing trout farm pollution by biological metrics and indices based on aquatic macrophytes and benthic macroinvertebrates : A case study. Ecological Indicators, 11(3), 911-917.

Chowdhury, S. U., Othman, F., Jaafar, W. Z. W., Mood, N. C., \& Adham, I. (2018). Assessment of pollution and improvement measure of water quality parameters using scenarios modeling for Sungai Selangor Basin. Sains Malaysiana, 47(3), 457-469. doi:10.17576/jsm-2018-4703-05

Coldebella, A., Gentelini, A. L., Piana, P. A., Coldebella, P. F., Boscolo, W. R., \& Feiden, A. (2018). Effluents from fish farming ponds : A view from the perspective of its main components. Sustainability, 10(3), 1-16. doi:10.3390/su10010003

Daniel, R., \& Kawasaki, N. (2016). The distribution of heavy metals and nutrients along Selangor River and its adjacent mining ponds, Malaysia. International Journal of Advances in Agricultural \& Environmental Enginering, 3(2), 241-244. doi:10.15242/IJAAEE.A0516012

Diana, J. S. (2009). Aquaculture production and biodiversity conservation. BioScience, 59(1), 27-38. doi:10.1525/bio.2009.59.1.7

Etemi, F. Z., Bytyçi, P., Ismaili, M., Fetoshi, O., Ymeri, P., Shala-Abazi, A., \& Czikkely, M. (2020). The use of macroinvertebrate based biotic indices and diversity indices to evaluate the water quality of Lepenci river basin in Kosovo. Journal of Environmental Science and Health - Part A Toxic/Hazardous Substances and Environmental Engineering, 55(6), 748-758. doi:10.1080/10934529.2020.1738172

Fierro, P., Bertrán, C., Tapia, J., Hauenstein, E., Peña-Cortés, F., Vergara, C., \& Vargas-Chacoff, L. (2017). Effects of local land-use on riparian vegetation, water quality, and the functional organization of macroinvertebrate assemblages. Science of the Total Environment, 609, 724-734. doi:10.1016/j. scitotenv.2017.07.197

Fulazzaky, M. A., Seong, T. W., \& Masirin, M. I. M. (2010). Assessment of water quality status for the Selangor River in Malaysia. International Journal of Water,Air, and Soil Pollution, 205(1-4), 63-77. doi:10.1007/ s11270-009-0056-2

HACH. (2007). DR 2800 Spectrophotometer procedures manual (2nd Ed.). USA: Hach company.

Hamid, S. A., Md Rawi, C. S., Dieng, H., Ahmad, A. H., Satho, T., \& Miake, F. (2011). Seasonal changes in mayfly communities and abundance in relation to water physicochemistry in two rivers at different elevations in northern Peninsular Malaysia. Wetland Science, 9(3), 240-250. 
Hamzah, U., Samsudin, A. R., \& Malim, E. P. (2007). Groundwater investigation in Kuala Selangor using vertical electrical sounding (VES) surveys. Envrionemntal Geology, 51(8), 1349-1359. doi:10.1007/ s00254-006-0433-8

Hanafi, H. H., Arshad, M. A., \& Yahaya, S. (1995). Report on a regional study and workshop on the environmental assessment and management of aquaculture development. Bangkok, Thailand. Retrieved November 08, 2019 from http://www.fao.org/3/ac279e/AC279E13.htm.

Harun, S., Al-shami, S. A., Ramzah, D., Mohamed, M., \& Abdullah, M. H. (2015). Water quality and aquatic insects study at the Lower Kinabatangan River Catchment, Sabah: In response to weak La Niña event. Sains Malaysiana, 44(4), 545-558. doi:10.17576/jsm-2015-4404-09

Hasmi, N. A., Ramlan, N., Musa, N. N., \& Faizzainuddin, M. A. (2017). Influence of physiochemical parameters on abandance of aquatic insects in rivers of Perak, Malaysia. International Journal of Advances in Science Engineering and Technology, 5(4), 68-72.

Hatami, R., Soofiani, N. M., Ebrahimi, E., \& Hemami, M. (2011). Evaluating the aquaculture effluent impact on macroinvertebrate community and water quality using BMWP index. Journal of Environmental Studies, 37(59), 13-15.

Hilsenhoff, W. L. (1988). Rapid field asessment of organic pollution with a family-level biotic index. Journal of the North American Benthological Society, 7(1), 65-68. doi:10.2307/1467832

Kang, H., Bae, M., Lee, D., Hwang, S., Moon, S., \& Park, Y. (2017). Distribution patterns of the freshwater oligochaete Limnodrilus hoffmeisteri influenced by environmental factors in streams on a Korean nationwide scale. Water, 9(12), 1-11. doi:10.3390/w9120921

Karimi, J. M., Takami, G. A., Khara, H., \& Abbaspour, R. (2016). Influence of trout farm effluents on water quality parameters and benthic macroinvertebrates. Iranian Journal of Fisheries Sciences, 15(1), 133-143.

Kawasaki, N., Kushairi, M. R. M., Nagao, N., Yusoff, F., Imai, A., \& Kohzu, A. (2016a). Release of nitrogen and phosphorus from aquaculture farms to Selangor River, Malaysia. International Journal of Environmental Science and Development, 7(2), 113-116. doi:10.7763/IJESD.2016.V7.751

Kawasaki, N., Kushairi, M. R. M., Nagao, N., Yusoff, F., Imai, A., \& Kohzu, A. (2016b). Seasonal changes of nutrient distributions along Selangor River, Malaysia. International Journal of Advances in Chemical Engineering and Biological Sciences, 3(1), 113-116. doi:10.15242/ijacebs.a0516011

Kim, D. H., Chon, T. S., Kwak, G. S., Lee, S. B., \& Park, Y. S. (2016). Effects of land use types on community structure patterns of benthic macroinvertebrates in streams of urban areas in the South of the Korea Peninsula. Water, 8(5), 1-18. doi:10.3390/w8050187

Kirkag, M. U., Pulatsu, S., \& Topcu, A. (2009). Trout farm effluent effects on water sediment quality and benthos. Clean, 37(4-5), 386-391. doi:10.1002/clen.200800212

Kroll, S. A., Llacer, C. N., De La Cruz Cano, M., \& De Las Heras, J. (2009). The influence of land use on water quality and macroinvertebrate biotic indices in rivers within Castilla-La Mancha(Spain). Limnetica, 28(2), 203-214. 
Kullasoot, S., Intrarasattayapong, P., \& Phalaraksh, C. (2017). Use of benthic macroinvertebrates as bioindicators of anthropogenic impacts on water quality of Mae Klong river, Western Thailand. Chiang Mai Journal of Science, 44(4), 1356-1366.

Lalonde, B. A., Garron, C., \& Mercier, V. (2016). Analysis of benthic invertebrate communities downstream of land-based aquaculture facilities in Nova Scotia,Canada. Cogent Environmental Science, 2(1), 1-11. doi:10.1080/23311843.2015.1136099

Lembaga Urus Air Selangor. (2014). Sungai Selangor basin management plan 2015 - 2020. Selangor, Malaysia: Lembaga Urus Air Selangor and Selangor Management Authority.

Lembaga Urus Air Selangor. (2015). State of the river report 2015 Sungai Selangor. Selangor, Malaysia: Lembaga Urus Air Selangor.

Li-na, D., Yan-e, J., Xiao-yong, C., Jun-xing, Y., \& Aldridge, D. (2017). A family-level macroinvertebrate biotic index for ecological assessment of lakes in Yunnan, China. Water Resources, 44(6), 864-874. doi:10.1134/S0097807817090020

Ling, E. G. L. (2010). Macroinvertebrates in disturbed and undisturbed sites in Asap, Belaga. (Unpublished B.Sc. Thesis). Universiti Malaysia Sarawak, Malaysia.

Loch, D. D., West, J. L., \& Perlmutter, D. G. (1996). The effect of trout farm effluent on the taxa richness of benthic macroinvertebrates. Aquaculture, 147(1-2), 37-55. doi:10.1016/s0044-8486(96)01394-4

Mandaville, S. M. (2002). Benthic macroinvertebrates in taxa tolerance values, metrics, and protocols. Nova Scotia, Canada: Soil \& Water Conservation Society of Metro Halifax.

Martins, R. T., Stephan, N. N. C., \& Alves, R. G. (2008). Tubificidae (Annelida : Oligochaeta ) as an indicator of water quality in an urban stream in southeast Brazil. Acta Limnologica Brasiliensis, 20(3), 221-226.

Merritt, R. W., \& K.W. Cummins. (1996). An introduction to the aquatic insects of North America (3rd ed.). Dubuque, Iowa: Kendal/Hunt Publishing Company.

Minoo, C. M., Ngugi, C. C., Oyoo-okoth, E., Muthumbi, A., Sigana, D., Mulwa, R., \& Chemoiwa, E. J. (2016). Monitoring the effects of aquaculture effluents on benthic macroinvertebrate populations and functional feeding responses in a tropical highland headwater stream (Kenya). Aquatic Ecosystem Health and Management, 19(4), 1-10. doi:10.1080/14634988.2016.1258896

Minoo, M. C. (2015). Impacts of aquaculture on water quality and economic benefits in central Kenya: A case study of Gatundu south constituency. (Unpublished M.Sc. Thesis). University of Nairobi. Retrived November 25, 2019 from http://erepository.uonbi.ac.ke/handle/11295/90072.

Miserendino, M. L., \& Gullo, B. S. (2014). Occurrence of Hirudinea species in a post urban reach of a Patagonian mountain stream. Iheringia, Série Zoologia, 104(3), 308-313. doi:10.1590/1678-476620141043308313

Mishra, P., Pandey, C. M., Singh, U., Gupta, A., Sahu, C., \& Keshri, A. (2019). Descriptive statistics and normality tests for statistical data. Annals of Cardiac Anaesthesia, 22(1), 67-72. doi:10.4103/aca. aca_157_18 
Moura, R. De, Souto, G., Facure, K. G., Pavanin, L. A., \& Jacobucci, G. B. (2011). Influence of environmental factors on benthic macroinvertebrate communities of urban streams in Vereda habitats, Central Brazil. Acta Limnologica Brasiliensia, 23(3), 293-306. doi:10.1590/s2179-975x2012005000008

Muhazar, A., Othman, M. S., Kutty, A. A., \& Desa, M. N. (2013). Mornitoring urban river water using macroinvertabrate and physico-chemical parameters: Case study of Penchala River, Malaysia. Biological Sciences, 13(6), 474-482. doi:10.3923/jbs.2013.474.482

Mustow, S. E. (2002). Biological moritoring of rivers in Thailand: use and adaptation of the BMWP score. Hydrobiologia, 479(1-3), 191-229.

Namin, J. I., Sharifinia, M., \& Makrani, A. B. (2013). Assessment of fish farm effluents on macroinvertebrates based on biological indices in Tajan River (north Iran). Caspian Journal of Environmental Sciences Assessment, 11(1), 29-39.

Oliveira, A., \& Callisto, M. (2010). Benthic macroinvertebrates as bioindicators of water quality in an Atlantic forest fragment. Journal Iheringia, Série Zoologia, 100(4), 291-300. doi:10.1590/s007347212010000400003

Othman, F., SadekUddin, M. C., \& Sakai, N. (2014). Assessment of microorganism pollution of Selangor River, Malaysia. International Journal of Advances in Agricultural and Environmental Engineering, $1(2), 203-206$.

Petrin, Z., Laudon, H., \& Malmqvist, B. (2007). Does freshwater macroinvertebrate diversity along a pHgradient reflect adaptation to low pH?. Freshwater Biology, 52(11), 2172-2183. doi:10.1111/j.13652427.2007.01845.x

Prommi, T., \& Payakka, A. (2015). Aquatic insect biodiversity and water quality parameters of streams in Northern Thailand. Sains Malaysiana, 44(5), 707-717. doi.org/10.17576/jsm-2015-4405-10

Rak, A., Said, I., \& Mohamed, M. (2011). Effects of land use on benthic macroinvertebrate assemblages at three rivers in Endau catchment area, Kluang, Johor, Malaysia. Journal of Applied Sciences in Envrionmental Sanitation, 6(2), 97-103.

Rak, A., Said, I., Mohamod, M., \& Abas, A. (2014). A preliminary benthic macroinvertebrates survey of Gunung Belumut recreational forest, Kluang, Johor, Malaysia. Journal of Wildlife and Parks, 27, 103-110.

Saremi, A., Saremi, K., Saremi, A., Sadeghi, M., \& Sedghi, H. (2013). The effect of aquaculture effluents on water quality parameters of Haraz River. Iranian Journal of Fisheries Sciences, 12(2), 445-453.

Seyam, M., \& Othman, F. (2015). Long-term variation analysis of a tropical river's annual streamflow regime over a 50-year period. Theoretical and Applied Climatology, 121(1-2), 71-85. doi:10.1007/s00704-014$1225-9$

Shannon, C. E. (1948). A mathematical theory of communication. Bell System Technical Journal, 27(3), $379-423$.

Sharma, K. K., \& Chowdhary, S. (2011). Macroinvertebrate assemblages as biological indicators of pollution in a Central Himalayan River, Tawi (J \& K). International Journal of Biodiversity and Conservation, $3(5), 167-174$. 
Simpson, E. H. (1949). Measurement of diversity. Nature, 163(4148), 688.

Soonthornvipat, S., Soonthornvipat, P., \& Chaibu, P. (2012, January, 10-12). Aquatic worms for aquaculture. In Proceedings of the 1st Annual PSU Phuket International Conference (pp. 1-5). Phuket, Thailand

Surtikanti, H. K. (2016). Uncertainty result of biotic index in analysing the water quality of Cikapundung river catchment area, Bandung. In T. Hidayat, A. B. D. Nandiyanto, A. Jupri, E. Suhendi, \& H. S. H. Munawaroh (Eds.), Proceedings of the 3rd International Seminar on Mathematics, Science, and Computer Science Education (Vol. 1848). Bandung, Indonesia: AIP Publishing.

Tan, K. W., \& Beh, W. C. (2016). Evaluation of water quality and benthic macrointervebrates fauna relationship using principal component analysis (PCA): A case study of Cameron Highlands Malaysia. Environmental Management and Sustainable Development, 5(1), 187-208. doi:10.5296/emsd.v5i1.9399

Thorp, J. H., \& Lovell, L. L. (2014). Phylum Annelida. In J. H. Thorp \& D. C. Rogers (Eds.), Thorp and Covich's Freshwater Invertebrates (pp. 360-482). Amsterdam, Netherlands: Elsevier Publishing Company.

Verma, N., \& Singh, A. K. (2013). Development of biological oxygen demand biosensor for monitoring the fermentation industry effluent. ISRN Biotechnology, 2013, 1-6. doi:10.5402/2013/236062

Virbickas, T., Pliuraite, V., \& Kesminas, V. (2011). Impact of agricultural land use on macroinvertebrate fauna in Lithuania. Polish Journal of Environmental Studies, 20(5), 1327-1334.

Vizakat, L., Harkantra, S. N., \& Parulekar, A. H. (1991). Population ecology and community structure of subtidal soft sediment dwelling macro- invertebrates of Konkan, West coast of India. Indian Journal of Marine Science, 20(1), 40-42.

Yong, S. H., \& Yule, C. M. (2004). Fresh water Invertebrates of the Malaysian region. Kuala Lumpur, Malaysia: Akademi Sains Malaysia.

Young, S. S., Yang, H. N., Huang, D. J., Liu, S. M., Huang, Y. H., Chiang, C. T., \& Liu, J. W. (2014). Using benthic macroinvertebrate and fish communities as bioindicators of the Tanshui river basin around the greater Taipei area - Multivariate analysis of spatial variation related to levels of water pollution levels of water pollution. International Journal of Environmental Research and Public Health, 11(7), 7116-7143. doi:10.3390/ijerph110707116

Yusoff, A. (2015). Status of resource management and aquaculture in Malaysia. In M. R. R. Romana-Eguia, F. D. Parado-Estepa, N. D. Salayo, \& M. J. H. Lebata-Ramos (Eds.), Resource enhancement and sustainable aquaculture practices in Southeast Asia: Challenges in responsible production of aquatic species: Proceedings of the International Workshop on Resource Enhancement and Sustainable Aquaculture Practices in Southeast Asia. Iloilo, Philippines: Aquaculture Dept., Southeast Asian Fisheries Development Center.

Zhu, D., \& Chang, J. (2008). Annual variations of biotic integrity in the upper Yangtze River using an adapted index of biotic integrity (IBI). Ecological Indicators, 8(5), 564-572. doi:10.1016/j.ecolind.2007.07.004 
